FACTA UNIVERSITATIS

Series: Economics and Organization Vol. 17, N ${ }^{\circ} 1,2020$, pp. 27 - 41

https://doi.org/10.22190/FUEO190914003B

Original Scientific Paper

\title{
MACROECONOMIC DIVERGENCES AND ASYMMETRIC RESPONSES WITHIN THE EURO ZONE
}

\author{
UDC 336.7(4-672EU)
}

\section{Emilija Beker Pucar, Olgica Glavaški}

University of Novi Sad, Faculty of Economics in Subotica, Serbia

\begin{abstract}
The paper deals with the nominal and real divergences within the Euro-zone (EZ) as a background for asymmetric European Central Bank's (ECB's) monetary transmission. In order to shed more light into these issues, the descriptive analysis of key nominal and real indicators confirms the core-periphery dichotomy within original EZ12 members, as well as the specific position of the emerging EZ19 members. Monetary (interest rate) transmission is explored via estimated Vector Autoregression (VAR) model for the representatives of the core (Germany, France, Belgium), as well as the periphery (Portugal, Spain and Greece), in the period 1999Q1-2018Q4. Observing the transmission of ECB's interest rate (the shock) to gross domestic product (GDP) growth (the response), the results of variance decompositions and impulse responses indicate that interest rate channel works countercyclical in general. However, while stabilizing (countercyclical) effect is evident for the core (especially Germany), it is almost absent in the case of Greece. The conclusions highlight the vulnerability of the EZ in the sense of heterogeneous membership and, accordingly, asymmetric response to ECB's monetary impulse. Our findings support the arguments of numerous research papers in emphasizing core-periphery dualism, German dominance hypothesis, and "one size fits some" monetary policy.
\end{abstract}

Key words: Euro-zone, the core, the periphery, real and nominal divergence, ECB, monetary transmission.

JEL Classification: E52, E58, E61, F45.

Received September 14, 2019 / Revised November 18, 2019 / Accepted November 18, 2019 Corresponding author: Emilija Beker Pucar

University of Novi Sad, Faculty of Economics in Subotica, Segedinski put 9-11, 24000 Subotica, Serbia

E-mail: emilijabp@gmail.com 


\section{INTRODUCTION}

Monetary union, as a final stage of European economic integration, was formed in 1999. Euro-zone (EZ) initially consisted of $11 \mathrm{EU}$ members $\left(12^{\text {th }}\right.$ member was Greece starting from 2001) which accepted common currency by sacrificing monetary sovereignty. Until now, 19 EU members accepted the euro after demanding process of a monetary convergence. Monetary union is rigid exchange rate arrangement where crucial sacrifice is loss of monetary and exchange rate policy. Member countries expect higher benefits from common currency having in mind lower exchange rate risk, lower transaction costs, minimized risks from speculative attacks and, above all, an ambient of macroeconomic stability. Mentioned benefits outweigh sacrifices if trade and financial integration is deeper between member states, if production structure is more diversified, while capital and labour are mobile (Ricci, 1997; Horvath \& Komarek, 2002). If criteria for optimum currency area (OCA) are fulfilled (Mundell, 1961) the need for national monetary policy is mitigated making thus monetary union more sustainable (Rose, 2008). However, EZ is not created as an OCA (Vrňáková \& Bartušková, 2013; Koziara, 2016).

Some of doubts whether Europe fulfils OCA criteria were hypothetically exposed during eighties and nineties, even before concrete plans for monetary union were set, by for example Eichengreen (1991) and Feldstein (1997). Although Europe was seen as an ideal candidate for testing Mundell's OCA theory, some economists were aware of divergent economies in economic reality that impede the functioning of European monetary union. Burning problem of the EZ is the dichotomy between the core and periphery countries. On the one hand, there are export-oriented and mostly industrialized countries, such as Germany, the Netherlands, and Austria. On the other hand, there are countries dependent on imports and inflows of foreign direct investment, largely based on the service sector, such as Greece, Italy, Ireland, Portugal and Spain (named PIIGS by the acronym for the names of these periphery economies) (De Larosicre, 2012). It is the dichotomy that exposes the currency zone to asymmetric shocks with the resulting imbalances between member states. As Mundell (1961) also pointed out different economic conditions (differences in GDP per capita, labour mobility and/or productivity), different levels of development or different sectorial diversification may initiate the dysfunction or sub-optimality of the currency area.

The EZ crisis can be understood as the outcome of a structural imbalance between the core and the periphery countries (Lapavitsas et al., 2010; Sklias, 2012; Bartlett \& Prica, 2016). This paper analyses intra-EZ divergence as a background for asymmetric monetary responses to ECB's monetary contraction/expansion through descriptive and econometric analysis. After the Introduction section, Section 2 includes descriptive analysis of macroeconomic divergences of nominal (Subsection 2.1) and real indicators (Subsection 2.2) concerning the relation core-periphery-emerging EZ members. The econometric analysis within Section 3 is based on the estimated VAR model in which are included ECB's interest rate and GDP of selected core (Germany, France, Belgium) and periphery EZ countries (Greece, Spain, Portugal). The aim of the above analyses is to understand the divergent positions of the core and periphery, as well as the divergent responses of economic activities to ECB's monetary expansion/tightening for selected representatives of the core and the periphery. Finally, Section 4 highlights crucial concluding remarks. 


\section{THE DIVERGENCE OF NOMINAL AND REAL VARIABLES WITHIN THE EURO-ZONE}

It has emerged that one currency cannot fit all unless the member countries move swiftly to address the underlying causes of economic divergence (Micossi, 2015). Namely, the common monetary framework cannot function adequately with divergent members subject to asymmetric shocks. Nominal and real convergence of economies is important in analysing the optimality of the EZ because the closer the countries are, the more effective unique monetary authority will be. More effective monetary authority implies its successful counter-cyclical or stabilizing effect. Real convergence is primarily related to rising GDP growth rates in the process of catching up with developed EZ members, including narrowing differences of GDP per capita and productivity. The Maastricht criteria emphasize nominal convergence defined through nominal variables of inflation, interest rates, exchange rates, public debt and budget deficits. OCA theory stresses the degree to which real convergence is sufficient to allow economies to function synchronously within the EZ in order to reduce the risk of asymmetric shocks (Auf dem Brinke, Enderlein, \& Fritz-Vannahme, 2015; Franks et al., 2018).

It is a well-known fact that countries in the EZ are extremely heterogeneous from an economic viewpoint. Countries with large external surpluses, high GDP per capita levels, good GDP growth rates and low unemployment rates coexist with others faring worse along several of such economic indicators (Bonatti \& Fracasso, 2017). The descriptive analysis that follows will first look at the divergence of the initial member states (EZ12) in relation to the core-periphery EZ12. The core of EZ12 consists of Germany, France, Austria, Belgium, the Netherlands, Luxembourg, Finland, while the periphery of EZ12 are represented by Greece, Spain, Italy, Portugal and Ireland. The emerging part of EZ19 consists of the later integrated economies, that is, the former transition countries. Emerging EZ economies are Slovenia (since 2007), Cyprus and Malta (since 2008), Slovakia (since 2009), Estonia (since 2011), Latvia (since 2014) and Lithuania (since 2015).

\subsection{Nominal EZ Divergence}

Given the ECB's strict anti-inflation policy, the inflation rate converges (Figure 1, left) between the periphery, core and emerging EZ members in the period 2007-2018. Prior to the accession of the emerging EZ economies (2007-2015), their significant deviation was evident, but monetary convergence and meeting the Maastricht convergence criterion led to accelerated adjustment to the rest of the EZ. The overview of inflation stability in 2018 indicates the persistence of differences (Figure 1, right). The latest figures indicate that in 2018 the average inflation rate in the EZ was 1.8\%, which is in line with the ECB's proclaimed monetary strategy. However, there is a clear difference of about three percentage points between the least inflationary economy (Ireland - 0.7\%) and the most inflationary economy (Estonia - 3.4\%).

Greater convergence of interest rates than inflation produced lower real interest rates during the early years of the EZ, helping to fuel unsustainable capital inflows into lower income countries. However, the divergence of the nominal interest rate variable (another Maastricht criterion) is particularly pronounced in the post-crisis period (Figure 2). Markets were "blind" to whether the EZ was truly an OCA due to the prevailing assumption that a common currency entails shared risk. Nowhere is this false assumption more evident than in examining the interest rates of key EZ countries (De Larosičre, 

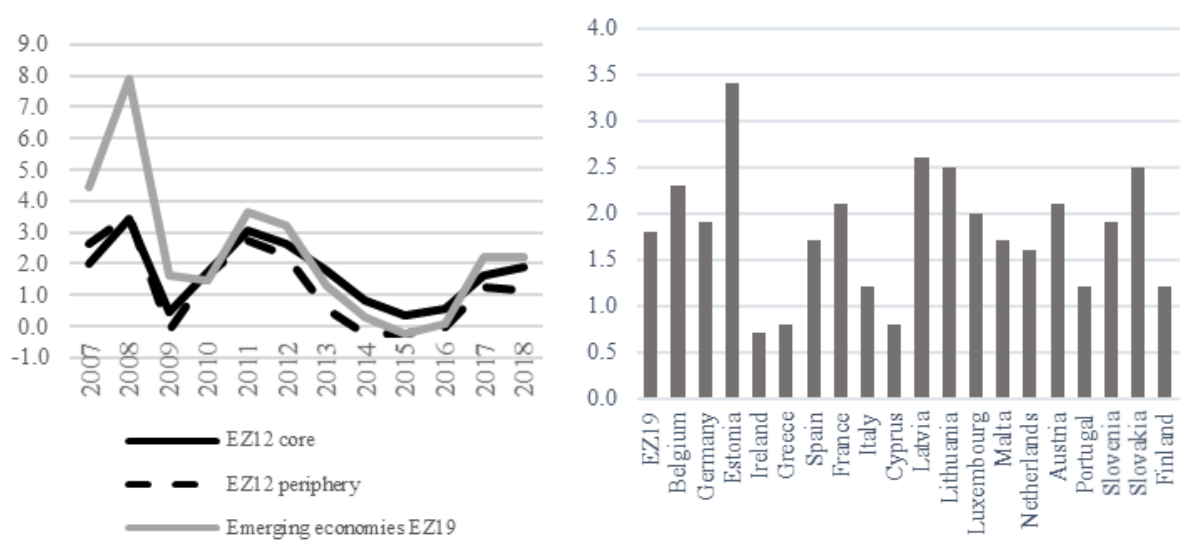

Fig. 1 Inflation rate for the core, periphery and emerging part of EZ19 in the period 2007-2018 (left) with the overview in 2018 (right)

Source: authors' review based on yearly Eurostat data (https://ec.europa.eu/eurostat/data/database).

2012). Due to shared risk beliefs, interest rates of EZ countries, from Germany to Greece, were on an almost identical trajectory in the period 2000-2009. It is only in 2009 that markets "woke up" with the understanding that Greek bonds (later bonds of other periphery economies) are not as secure as bonds of other EZ countries, mainly as a result of divergences between EZ members. When markets "awoke" to accept the reality of the divergence of EZ countries in 2009 and 2010, long-term interest rates diverged between countries and rose sharply for the countries considered most at risk.

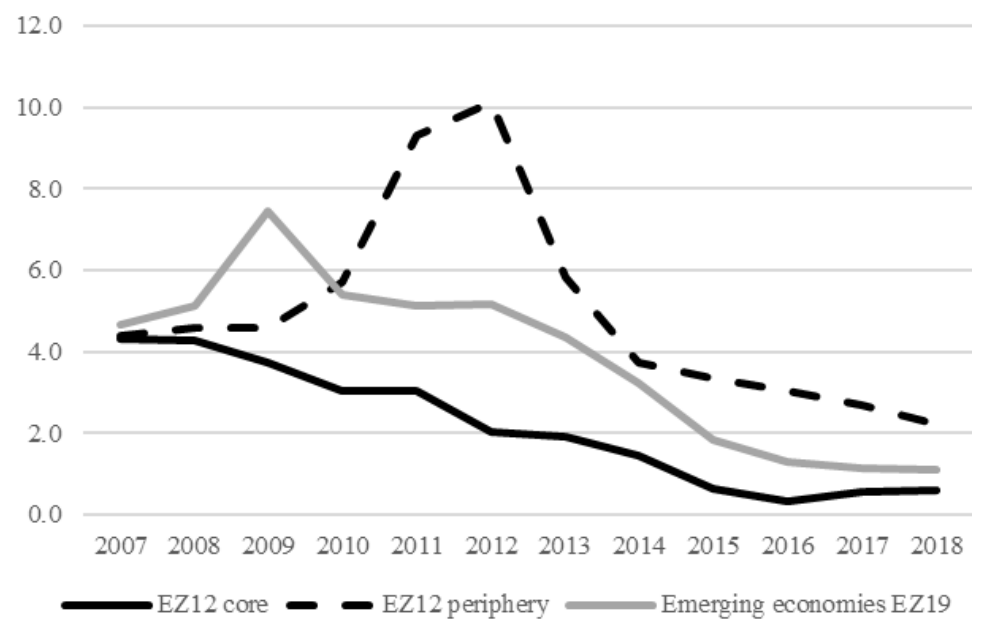

Fig. 2 The divergence of long-run interest rate (Maastricht criteria) in the core, periphery and emerging part of EZ19 in the period 2007-2018

Source: authors' review based on yearly Eurostat data (https://ec.europa.eu/eurostat/data/database). 
Having in mind that monetary policy is not under national monetary control, excessive fiscal easing was seen as the main problem within the EZ (Alessandrini et al., 2014; Schiliro, 2017). Each of the EZ member is responsible for implementing its own fiscal policy but is obliged to respect the Maastricht convergence criteria concerning low budget deficits (upper limit $3 \%$ of GDP) and public debt (up to 60\% of GDP). If a country's budget deficit is estimated to be excessive (exceeding the long-term benchmark), it may be possible to initiate procedures for sanctioning and monitoring the budget of a particular member state. Although fiscal discipline has been emphasized as one of the most important preconditions for EZ membership, most EZ countries have failed to stay within the set limits of the budget deficit. Figure 3 identifies the largest discipline in the public finance for the core countries in the period 2007-2018. In the process of monetary convergence and the EZ accession, emerging countries are rapidly approaching the EZ core. The problem is in the periphery EZ12 countries with the huge and deepening budget deficit (average 14\% in 2010) with the onset of shocks from the global crisis and the debt EZ crisis. The EZ debt crisis is evident in Figure 3. In addition to the budget deficit relative to GDP, another Maastricht criterion concerning public finance and fiscal policy can be observed in Figure 3. Figure 3 (right) shows the trend of public debt in the period 2007-2018 for the EZ12 core and periphery, as well as the emerging part of the EZ19. In the core countries, the public debt indicator was within the planned range, just like the budget deficit indicator. On average, emerging economies in the observed period recorded even lower levels of public debt compared to the EZ12 core and periphery. A key divergence in the core-periphery relation occurs in the post-crisis period when public debt rose sharply (on average) in the periphery countries. The finding is compatible with the previous indicator of an excessive budget deficit in the post-crisis period.
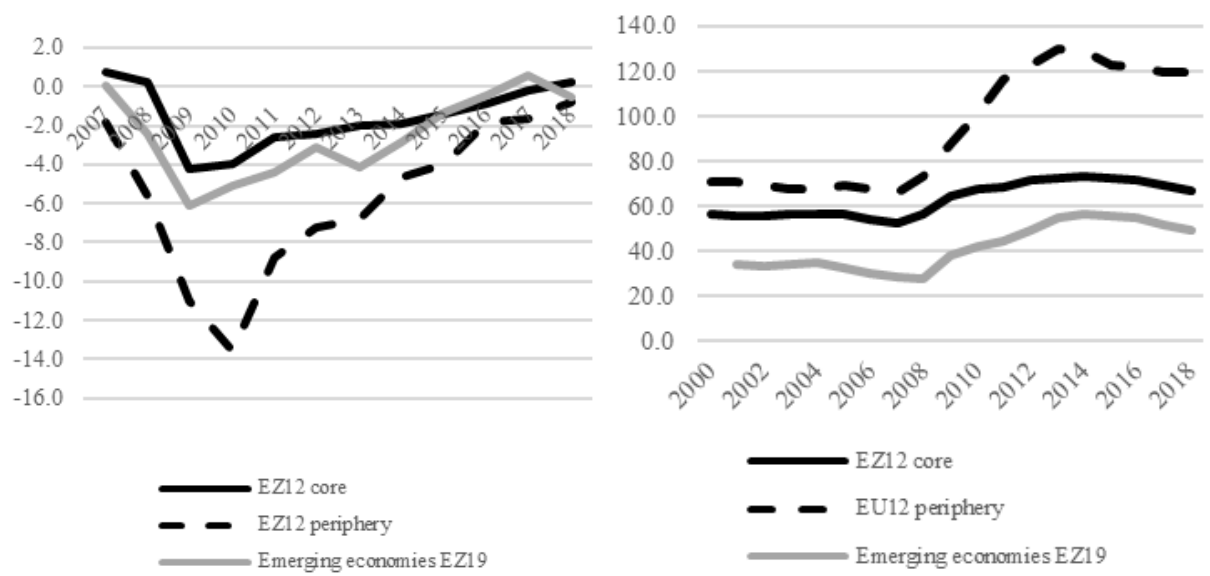

Fig. 3 Maastricht criteria related to public finance: budget deficit/GDP (left) and public debt/GDP (right) of EZ19 members in the period 2007-2018

Source: authors' review based on yearly Eurostat data (https://ec.europa.eu/eurostat/data/database).

Due to the divergent positions of public finances in the EZ member states, as well as the role of fiscal destabilization in the debt 2010 crisis, there is a perception that stronger fiscal integration is a necessary step for the EZ. Close coordination of fiscal policies would ensure compatibility of macroeconomic policies among member states to minimize economic 
fluctuations and maximize the effectiveness of the common monetary policy (European Council, 1989; De Grauwe, 2018). If countries reach a consensus on fiscal union with financial transfers between member states, then these transfers can serve as a replacement for the missing flexible exchange rate and even as a substitute for a rigid labour market (immobile labour and rigid wages). EZ members should implement a mechanism that provides financial support to member countries affected by asymmetric shock (Eichengreen, 1991; Feldstein, 1997; Dibooglu \& Horvath, 1997; Verdun, 2007; De Grauwe, 2009). The implemented stabilization mechanism would be of benefit not only to the recipient countries but also to all members due to economic and political stabilization of the unique currency area. Assuming that it is implemented reasonably, such a mechanism would be available to all monetary union member states and would not lead to permanent and unilateral transfers. Such an instrument should be available automatically and quickly. Otherwise, if decisions are to be made on a case-by-case basis, it will take a long time to reach political consensus (Baldwin \& Wyplosz, 2012).

\subsection{Real EZ Divergence}

While nominal convergence is more recent from the European integration point of view, underlined by the Maastricht treaty in the form of convergence criteria, real convergence is a longer-term phenomenon. Namely, real convergence is related to the approximation of real variables, such as the level of economic development, standard of living, productivity, etc. within countries that seek greater degree of economic integration. It can be stated that the initiators of European integration (Germany, France, Italy, Belgium, the Netherlands, Luxembourg), with the later accession of other EU countries (and later the EZ members), insisted from the very beginning on the real convergence for the sake of sustainability of shallower integration levels than monetary union. For the functioning of the customs union (common customs policy since 1967) and the common market (Single European Act since 1987) it was necessary to reduce the differences in the levels of economic development of the member states. However, sharing the same currency as the last stage of economic integration, imposed the need to adjust nominal variables that was formalized by the Maastricht criteria.

Although there was steady income convergence across EZ members in the decades leading up to the Maastricht treaty, income convergence among EZ12 countries slowed after Maastricht, while productivity among the EZ12 diverged under the single currency (Franks et al. 2018). Real convergence has not occurred among the initial EZ members. GDP growth and productivity growth have not reduced income disparities between richer and poorer countries. In contrast, there has been significant convergence among emerging EZ19 who have joined the EZ in the period 2007-2015. The lack of convergence between EZ12 could be attributed to several factors, notably structural rigidities, weak productivity growth, weak institutions and insufficient policies to address asset price booms (Del Hoyo et al., 2017).

Several years before the onset of the global economic crisis, all EZ members were in expansion and all went into recession after the crisis. The accumulation of imbalances in the first decade of the EZ became unsustainable and triggered a painful correction, which led to a double-dip recession in the EZ between 2009 and 2012 (Pierluigi \& Sondermann, 2018). However, significant differences are evident in terms of their post-crisis adjustment. While some countries have regained a stable economic growth trajectory and pre-crisis output levels, other countries have experienced a recurrent economic crisis (Figure 4). 

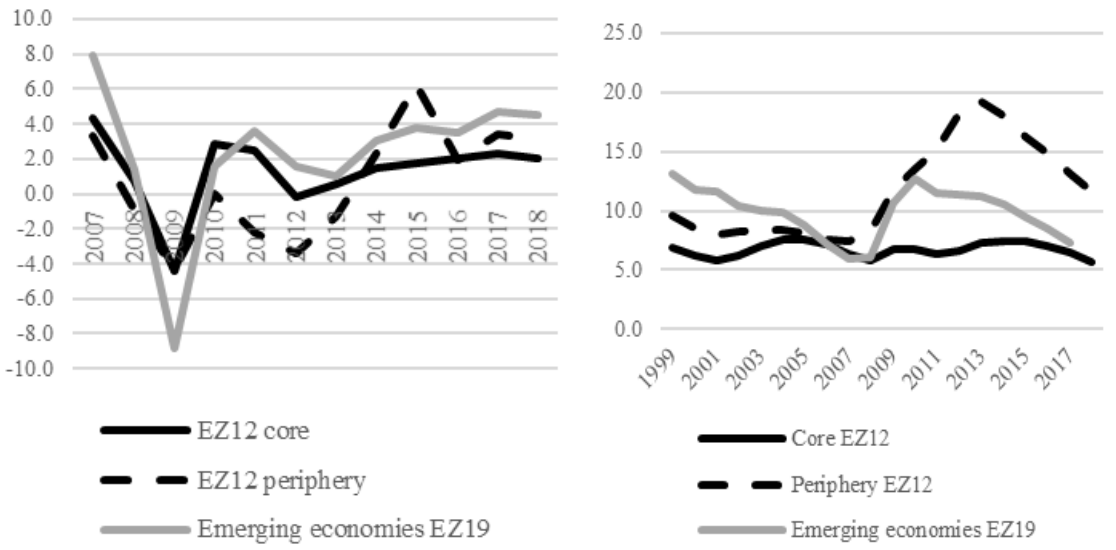

Fig. 4 The divergence of economic growth (left) and unemployment rate (right) between core-periphery-emerging economies of the EZ in the period 1999-2018

Source: authors' review based on yearly Eurostat data (https://ec.europa.eu/eurostat/data/database).

As Figure 4 shows, the structural break in the economic growth (left) and related unemployment rate (right) was evident in the EZ, especially for the periphery and emerging parts with the outbreak of the 2007/2008 global crisis. However, an asymmetric shock has hit the EZ since 2010 as a result of the debt crisis. Asymmetry due to the fact that periphery economies experienced another structural break in the wake of the 2011/2012 economic downturn. The debt crisis has severely affected the economic growth of mentioned economies, while other countries have been affected indirectly and, at worst, in a moderate manner. Cyprus, Greece, Ireland, Portugal and Spain had to seek financial support. Italy has attracted the attention of investors who doubted the sustainability of Italian long-term solvency. The bonds of the Italian government therefore recorded a high risk premium and the country faced significantly higher refinancing costs (Ehmer, 2017). This is why Italy is generally considered to belong to the EZ periphery. Other than Italy, the other founding members of European integration are the so-called EZ core (along with Austria and Finland). Their economic growth was mostly threatened by economic ties with the periphery economies, and in their case a slight decline in economic activity was evident as a result of the debt crisis (Figure 4, left).

Widening gap between the EZ core and the periphery concerning the unemployment rate as a real economy indicator is evident in the post-crisis period (Figure 4, right). While the core is close to full employment and their potential growth has not been affected by the last global crisis, secular stagnation is a concern in the periphery economies (Bartlett \& Prica, 2016, Onaran, 2018). Since the global crisis, the periphery has experienced a permanent reduction in their growth potential. Eleven years after the crisis, their economies still register unemployment rates higher than pre-crisis levels and, in most cases, at unacceptable two digit levels. Figure 4 (right graph) indicates that there was convergence of unemployment rates in the pre-crisis period, but it has been mainly reversed in the postcrisis period. The global crisis initiated sharp rise of unemployment in the case of EZ periphery and milder rise of unemployment in the case of emerging EZ economies. 


\section{HETEROGENEOUS REAL RESPONSES TO ECB'S MONETARY IMPULSE}

Weaker EZ economies recorded generally higher levels of inflation and unemployment. On the other hand, there are countries like Germany with the main priority of maintaining low inflation. The ECB's monetary decision-making was mostly criticized because it affects EZ members differently and could drive their economies out of alignment (Salvatore, 2002). The literature on the topic suggests a theory also known as the German Dominance Hypothesis (GDH), which explains the prevailing role of German's economic goals on the ECB's decision-making process. As Aizenman (2014) states, the euro is a currency without a state, under the dominance of Germany. Besides highlighting the divergence of EZ members, the main purpose of this paper is to shed some light into the question if the ECB's monetary policy is beneficial for the EZ members as a whole or only for a select group of countries, which have similar economic profiles. This research establishes the differential interest rate impact of the ECB's monetary policies on the EZ members with the expectations that the policy will benefit mostly the German economy and other economies with similar low-inflation targeting needs (the core), in contrast to others which face generally higher unemployment rates (the periphery).

The ECB's monetary policy is not effective if monetary transmission is asymmetric to the member states. Moreover, "one-size-fits-all" monetary policy has created problems for periphery economies with different needs from the core countries. The countercyclical or stabilizing effect of the ECB's policy on the core countries, with the absence of stabilization in the case of periphery economies, is empirically investigated by the forecast error variance decompositions and impulse response functions of the estimated VAR model. This type of model is widely used in the empirical literature dealing with the monetary transmission mechanism, as well as transmission of external shocks, e.g. Borghijs \& Kuijs (2004), Ito \& Sato (2006), Galesi \& Lombardi (2009), Polito \& Wickens (2012), Arratibel \& Michaelis (2014), Kapuściński et al. (2016), Serwa \& Wdowiński (2016), Ulrich (2018), etc. The VAR model is bivariate because it involves changes in the ECB's short-term interest rate ${ }^{2}$ and national $\mathrm{GDP}^{3}$ of the core (Germany, France, Belgium) and the periphery (Greece, Spain, Portugal). The impulse or the shock represents an unexpected change in the ECB's interest rate. The monetary transmission of the shock (interest rate channel) to variations in economic activities (the response) has been tracked for the aforementioned economies during four quarters. Counter-cyclicality is reflected in negative reaction of economic growth to the rise of supranational interest rate. The research period covers the start of EZ functioning until the last quarter of 2018, 1999:Q1-2018:Q4. Figure 5 shows the tendency of the ECB's interest rate over the mentioned period. In addition to the rigid position of supranational monetary authority at the beginning of the EZ functioning and another tightening with the outbreak of the debt crisis, the ECB takes a more relaxed stance with a sharp interest rate drop in the post-crisis period.

\footnotetext{
${ }^{2}$ Money market interest rate - quarterly data, the period 1999:Q1-2018:Q4, Eurostat.

${ }^{3}$ Nominal GDP (seasonally adjusted) - quarterly data, the period 1999:Q1-2018:Q4, International Financial Statistics, IMF.
} 


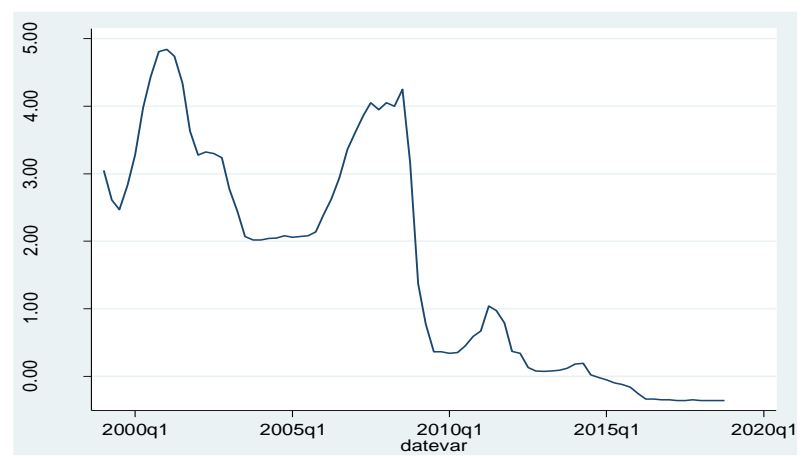

Fig. 5 ECB's money market interest rate in the period 1999:Q1-2018:Q4 Source: authors' review based on quarterly Eurostat data.

Figure 6 shows nominal GDP (seasonally adjusted) for Germany, France, Belgium (upper graphs) and Greece, Spain and Portugal (below graphs). The divergence in GDP trend is clearly evident in presented figures. In addition to a structural break in the crisis year, the core countries continue the path of economic expansion. On the other hand, Greek GDP has not yet recovered since the global crisis. In the case of Portugal and Spain, the recovery was slow. The induction of growth followed in 2015 , after years of economic stagnation.
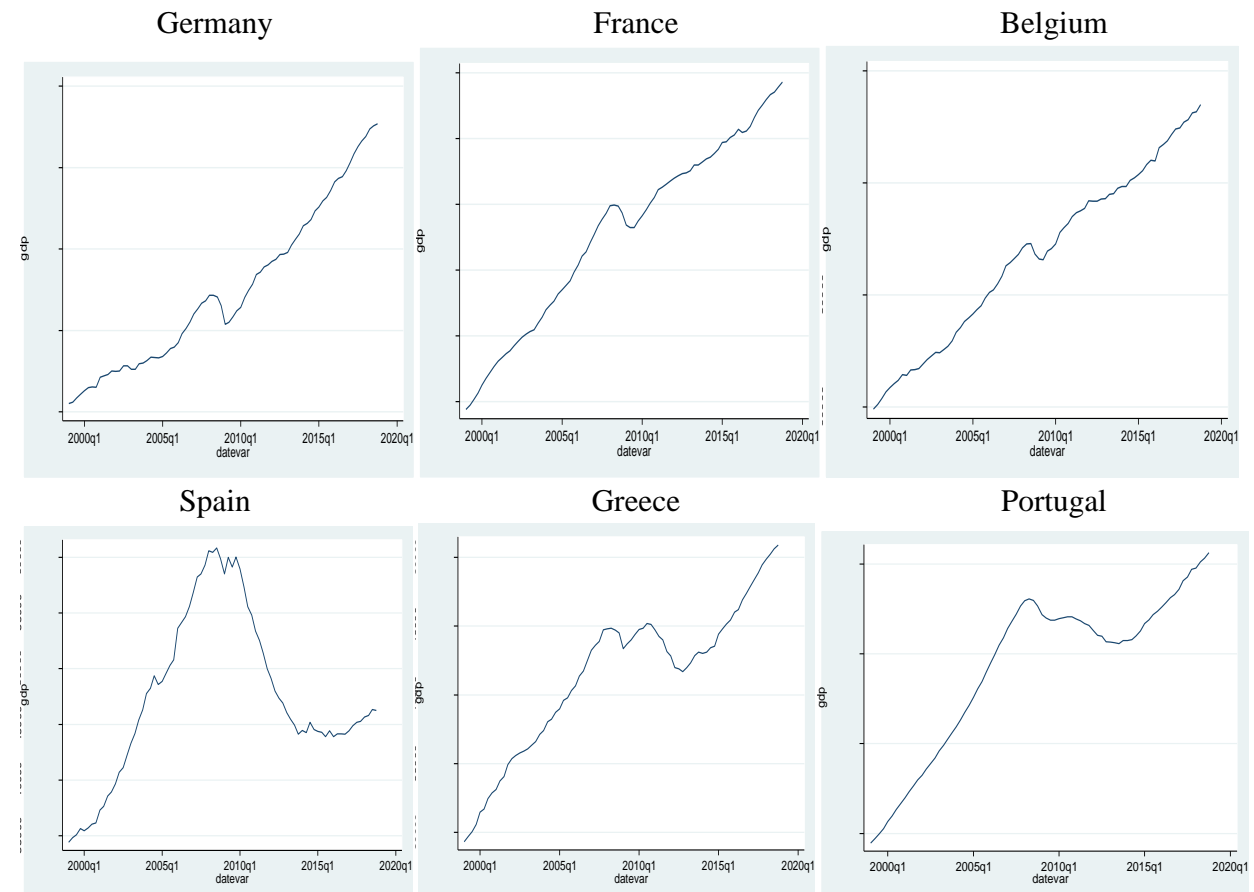

Fig. 6 Nominal GDP (seasonally adjusted) of EZ core (above) and periphery (below) representatives in the period 2000-2019

Source: authors' review based on quarterly data IMF International Financial Statistics. 
The VAR model estimation is preceded by stationarity tests of the ECB's interest rate and national GDP levels of selected core and periphery countries. The Dickey-Fuller and Phillips-Perron stationarity tests for both variables, and in all the economies examined, indicate acceptance of the null hypothesis. Therefore, the time series of the ECB's interest rate and the GDP of the EZ core and periphery countries are non-stationary. Nonstationarity indicates that the economic shock has a lasting effect on these time series and that after the effect of the asymmetric shock it is difficult and slow to return to the equilibrium path. The non-stationarity of GDP levels is not a good signal from the point of view of the functioning of monetary union, as asymmetric shocks initiate longer-term destabilization. The relation between individually non-stationary time series can be examined through the concept of cointegration or long-term equilibrium relationship. A confirmation of the cointegration of non-stationary time series via Johansen's cointegration test indicates the estimation of VEC (Vector Error Correction) model. Or, the rejection of the long-run equilibrium relationship of individually non-stationary time series (cointegration) suggests the estimation of VAR (Vector Autoregressive) model. The cointegration between the ECB's interest rate and national GDP levels is not confirmed. Therefore, the first differences of interest rate and national GDP are included in the VAR model estimation. The order of the VAR model is determined on the basis of information criteria (Akaike-AIC, Hana-QuinnHQIC, and Schwartz-Bayesian-SBIC). VAR model estimates do not automatically allow the derivation of forecast error variance decompositions and impulse response functions. Specifically, the stability of the VAR model, the absence of autocorrelation, and the normal distribution of the residuals of the estimated VAR model, should be previously confirmed. The results of variance decompositions and impulse responses are performed in order to analyse the effect of economic policy measures. In this case, it is of interest to find out how the sudden change in the ECB's short-term interest rate reflects on the economic activities of the selected core and periphery EZ countries. If a change in ECB's interest rate is differently transmitted to economic activities of investigated economies, then the action of the EZ supranational monetary authority is undoubtedly ineffective and asymmetric.

Table 1 shows the correlation coefficient between the ECB's interest rate and GDP of the selected countries. This numerical indicator, although cursory, indicates monetary asymmetry in the ECB's action for the core and the periphery.

Table 1 Correlation coefficient between short-run ECB's interest rate and GDP for selected EZ core and periphery countries in the period 1999:Q1-2018:Q4

\begin{tabular}{cccccc}
\hline Germany & France & Belgium & Portugal & Spain & Greece \\
\hline$-0,80$ & $-0,79$ & $-0,82$ & $-0,68$ & $-0,65$ & $-0,07$ \\
\hline \multicolumn{7}{c}{ Source: The authors. }
\end{tabular}

The effect of the ECB's monetary policy is counter-cyclical, as indicated with negative signs of correlation coefficients. However, it is clearly observed that counter-cyclical influence is more pronounced in the case of the core countries. Significant stabilizing effect is evident in the case of Belgium, Germany and France, while stabilization is moderate in the case of Portugal and Spain, and almost absent in the case of Greece. Figure 7 shows the results of forecast error variance decomposition for the economic growth of selected EZ economies over the observed period. 


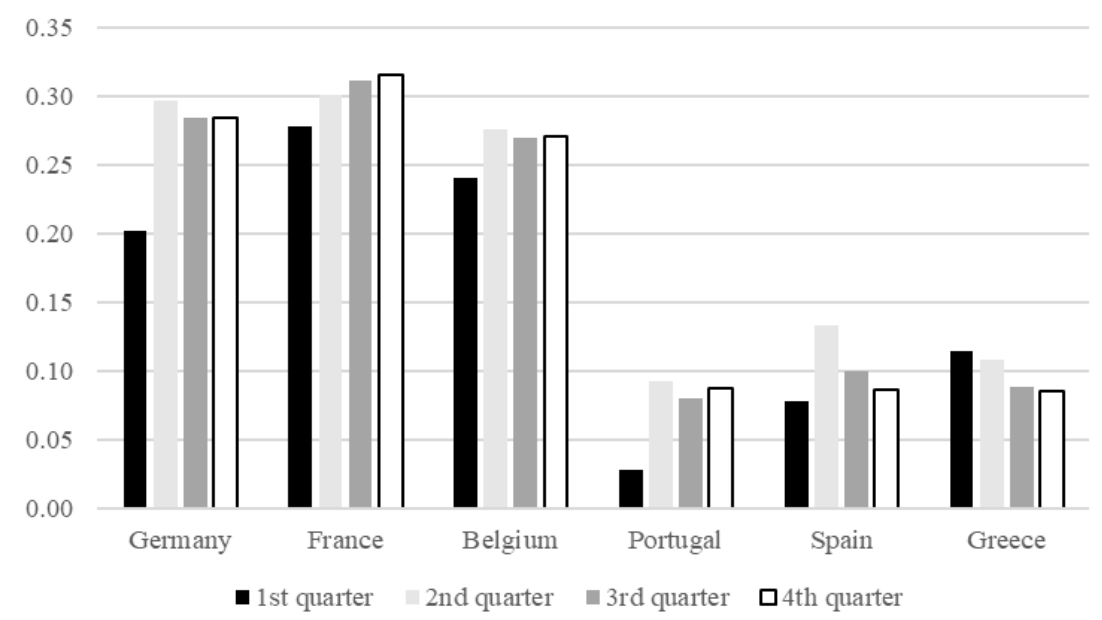

Fig. 7 Forecast error variance decomposition of economic growth/fall as a response to the ECB's interest rate change (shock) during four quarters Source: The authors.

The results of variance decompositions of the economic growth for selected core and periphery EZ countries confirm the expectation that the countercyclical effect of the ECB's monetary policy is more pronounced for the core. In the case of Germany, a change in ECB's interest rates causes a $20 \%$ change in economic activity, with an impact growing in the second quarter to $30 \%$. A similar effect is evident in the case of France and Belgium. However, the change in the ECB's interest rates affects only 3\% of GDP variations in the first quarter and $9 \%$ of variations in the second quarter in the case of Portugal. More generally, about $9 \%$ of GDP variations in all periphery countries can be explained by the impact of the ECB after four quarters. The same impact in the core countries is in range of $27-32 \%$ after four quarters. The strength of the countercyclical impact or monetary asymmetry between core-periphery is clear on the basis of above mentioned empirical findings.

Further analysis of the ECB's interest rate transmission to the real economic activities of the core and the periphery implies examination of the impact direction (pro- vs. countercyclicality), the intensity (stronger or weaker real effect), as well as the length of the monetary impact during 4 quarters. The variance decomposition results do not indicate the direction and duration of the mentioned monetary transmission. In that purpose, impulse response functions are presented in Figure 8.

The results indicate that the effect of ECB's monetary policy is generally countercyclical in the case of the observed EZ members. Countercyclical effect occurs mainly in the $2^{\text {nd }}$ quarter (Figure 8). However, this countercyclical effect on the real economy is relatively weak in the case of Greece, Portugal and Belgium. The impact is relatively stronger in the case of Spain, but the strongest in the case of two key core economies - France and Germany. As the Figure 8 shows, by far the strongest countercyclical effect is observed in the case of Germany, confirming the best fit of the ECB's policy to this key core economy. 


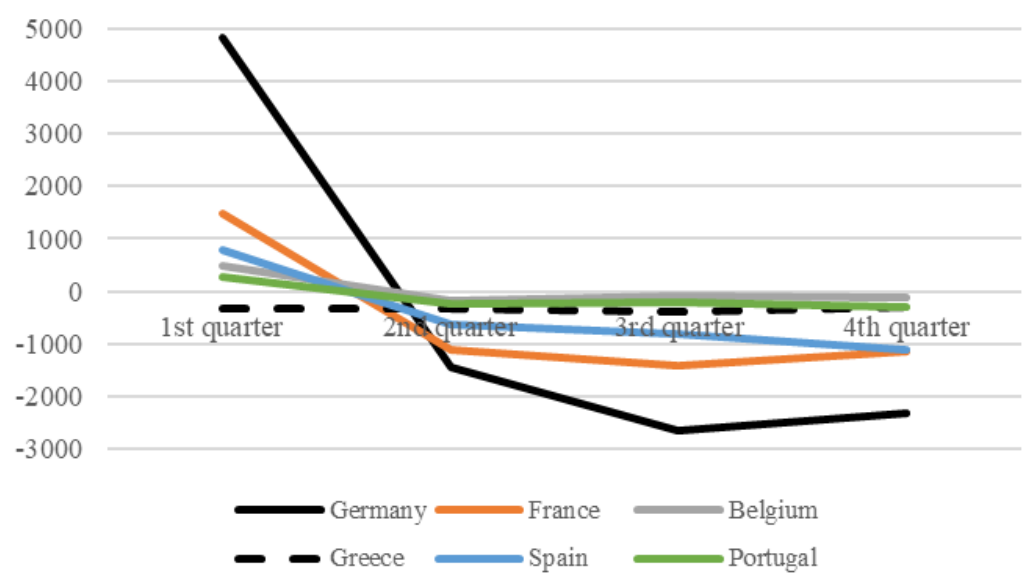

Fig. 8 Impulse response functions - the response of GDP growth of selected EZ members to the change of ECB's money market interest rate during 4 quarters Source: The authors.

Asymmetric and heterogeneous responses of EZ member states to ECB's monetary impulses, especially related to the core-periphery dichotomy, German dominance hypothesis, and "one size fits some" monetary policy are also emphasized in Kool (2005), Hendricks \& Kempa (2008), Petrova (2010), Micossi (2015), Wortmann \& Stahl (2016), Botta, Tippet \& Onaran (2018), etc.

\section{CONCLUDING REMARKS}

"Diversity in unity" is the famous European slogan, and as far as economic diversity is concerned, this motto seems appropriate. Economic heterogeneity in the EZ is a well-known phenomenon, ranging from employment to growth rates, from public debt and budget deficit to wage and price dynamics. Convergence criteria should not be viewed as a temporary adjustment aimed at adopting a common currency. Specifically, the common currency and monetary union are threatened per se if convergence is not maintained in the long run. The global crisis has highlighted already accumulated macroeconomic imbalance and vulnerability of the EZ in the pre-crisis period, culminating with the debt EZ crisis. The lesson of crisis episodes underlines the need to prevent the aforementioned imbalances within the single currency area, as divergence will lead sooner or later to the EZ crisis under sudden external shocks.

Despite vast literature dealing with the issue of EZ vulnerability, the paper aims to contribute with an up-to-date descriptive and econometric analysis of macroeconomic divergences among core-periphery-emerging EZ members and consequential asymmetric responses to supranational monetary measures. This paper argues that the EZ seems to be a rather complicated framework for certain EZ members like Greece, Portugal, Spain, Ireland, and Italy, namely the weaker or periphery economies. Here we especially stress nominal and real divergences having in mind original EZ12 core-periphery dichotomy, with even more diversity added by emerging EZ19 economies. In the periods during which asymmetric 
shocks create fundamentally different economic conditions in the EZ, monetary policy is not a very efficient stabilizer. The ECB's monetary policy has to do justice to the needs of all member states simultaneously and may not be geared to the requirements of individual member states only. However, the effectiveness or stabilization role of supranational monetary policy is weak in mutually divergent economies, subject to asymmetric shocks. The results confirm that ECB's interest rate monetary transmission is counter-cyclical for the core countries, while for the periphery countries it is a relatively weak stabilization mechanism. Especially, the ECB's impulse is most compatible with the German countercyclical need, then French, and in the least extent adjusted to the Greek situation.

The convergence of key nominal and real variables is necessary for the proper functioning of the monetary union. However, structural differences of EZ members can hardly be narrowed significantly in a relatively short period of time. Therefore, persistent economic divergence is a key challenge to keep European monetary union sustainable. Important actions have already been taken in establishing the Banking Union, monitoring and coordinating macroeconomic policies more closely, and pushing for greater structural reforms through the European Semester, Macroeconomic Imbalances Procedure, and other initiatives. Nevertheless, long term success of the EZ depends on continuing process of political unification. Budgetary union (and thus political union) is needed, but the willingness today to move in the mentioned direction is relatively weak. This will continue to make the EZ a fragile monetary arrangement, without possibility to predict and guarantee its long-term success.

\section{REFERENCES}

Aizenman, J. (2014). The Eurocrisis: Muddling Through, or On the Way to a More Perfect Euro Union? (NBER Working Paper, 20242), Cambridge, MA: The National Bureau of Economic Research

Arratibel, O., \& Michaelis, H. (2014). The impact of monetary policy and exchange rate shocks in Poland: Evidence from a time-varying VAR (ECB Working Paper Series 1636(16)), Frankfurt: European Central Bank.

Alessandrini, P., Fratianni, M., Hughes, A., \& Presbitero, F. (2014). External Imbalances and Fiscal Fragility in the Euro Area. Open Economies Review, 25(1), 3-34.

Auf dem Brinke, A., Enderlein, H., \& Fritz-Vannahme, J. (2015). What kind of convergence does the euro area need?. Gütersloh: Bertelsmann Stiftung und Jacques Delors Institut - Berlin.

Baldwin, R., \& Giavazzi, F. (2016). How to Fix Europe's Monetary Union: Views of Leading Economists. London, UK: CEPR Press.

Baldwin, R., \& Wyplosz, C. (2012). The Economics of European Integration. 4th revised edition, McGraw Hill Higher Education.

Bartlett, W., \& Prica, I. (2016). Interdependence between Core and Peripheries of the European Economy: Secular Stagnation and Growth in the Western Balkans (LEQS Paper, 1104/2016), London, UK: European Institute, London School of Economics.

Bonatti, L., \& Francasso, A. (2017). Adressing the Core-Periphery Imbalances in Europe: Resource Misallocation and Expansionary Fiscal Policies (EconPol Working Paper November Volume 1, 06/2017), Munich: European Network for Economic and Fiscal Policy Research.

Borghijs, A., \& Kuijs, L. (2004). Exchange Rates in Central Europe: A Blessing or a Curse? (IMF Working Paper WP/04/02), Washington, DC: International Monetary Fund.

Botta, A., Tippet, B., \& Onaran, O. (2018). Core-Periphery Divergence and Secular Stagnation in the Eurozone - Macroeconomic Evidence and Policy Proposals beyond Conventional Monetary Policy (FEPS Policy Paper, June 2018), Brussels: Foundation For European Progressive Studies.

De Grauwe, P. (2009). The euro at ten: Achievements and challenges. Empirica, 36(1), 5-20.

De Grauwe, P. (2018). Core-Periphery in the Eurozone. Conference "The Future of Central Banking" in Honour of Vitor Constancio, Frankfurt, 16-17 May, 2018. 
De Larosičre, J. (2012). The Long-term Outlook for the European Project and the Single Currency (Occasional Paper, 84), Washington, D.C.: The Group of Thirty.

Del Hoyo, J. L. D., Dorrucci, E., Heinz, F. F., \& Muzikarova, S. (2017). Real convergence in the euro area: a long-term perspective (ECB Ocassional Paper Series, 203), Frankfurt: European Central Bank.

Dibooglu, S., \& Horvath, J. (1997). Optimum currency areas and the European monetary unification. Contemporary Economic Policy, 15(1), 37-49.

Ehmer, P. (2017). Asymmetric within the euro area - absorption mechanism needed. KfW Research Economics in Brief, 137.

Eichengreen, B. (1991). Is Europe an Optimal Currency Area? (NBER Working Paper, 3579), Cambridge, MA: The National Bureau of Economic Research.

European Council, Committee for the Study of Economic and Monetary Union. (1989). Report on economic and monetary union in the European Community (Delors Report). http://aei.pitt.edu/1007/1/monetary_delors.pdf

Feldstein, M. (1997). EMU and International Conflict. Foreign Affairs Nov-Dec, 1997, 60-73.

Franks, J., Barkbu, B., Blavy, R., Oman, W., \& Schoelermann, H. (2018). Economic Convergence in the Euro Area: Coming Together or Drifting Apart? (IMF Working Paper, WP/18/10), Washington, DC: International Monetary Fund, European Department.

Galesi, A., \& Lombardi, M. (2009). External shocks and international inflation linkages: a global VAR analysis (ECB Working Paper No. 1062), Frankfurt: European Central Bank.

Ito, T., \& Sato, K. (2006). Exchange rate changes and inflation in post-crisis Asian economies: VAR analysis of the exchange rate pass-through (NBER Working Paper 12395), Cambridge; MA: National Bureau of Economic Research.

Horvath, R., \& Komarek, L. (2002). Optimum Currency Area Theory: An Approach for Thinking About Monetary Integration (Warwick Economics Research Papers, 647), The Coventry, UK: University of Warwick, Department of Economics.

Kapuściński, M., Kocięcki, A., Kowalczyk, H., Łyziak, T., Przystupa, J., Stanisławska, E., Sznajderska, A., \& Wróbel, E. (2016). Monetary policy transmission mechanism in Poland. What do we know in 2015? (NBP Working Papers 249), Warszava: National Bank of Poland.

Koziara, B. (2013). The Eurozone: An Optimal Currency Area. A Senior Honour Thesis. The University of Michigan.

Kool, C. J. M. (2005). What Drives ECB Monetary Policy? (Tjalling C. Koopmans Research Institute Discussion Paper Series, 05-03), Utrecht, the Netherlands: Utrecht School of Economics, Untrecht University.

Lapavitsas, C., Kaltenbrunner, A., Lindo, D., Michell, J., Painceira, J.P., Pires, E., Powell, J., Stenfors, A., \& Teles, N. (2010). Eurozone crisis: beggar thyself and thy neighbour. Journal of Balkan and Near Eastern Studies, 12(4), 321-373.

Micossi, S. (2015). The Monetary Policy of the European Central Bank. CEPS Special Report No. 109.

Mundell, R. A. (1961). A Theory of Optimum Currency Areas. The American Economic Review, 51(4), 657-665.

Petrova, T. D. (2010). How European is the European Central Bank's monetary policy? Estimating the differential impact of the ECB's interest rate policy on the Eurozone states. (Honors Projects Paper, 109), Bloomington: Illinois Wesleyan University.

Pierluigi, B., \& Sondermann, D. (2018). Macroeconomic Imbalances in the Euro Area: Where Do We Stand? (ECB Occasional Paper, 211), Frankfurt: European Central Bank.

Polito, V., \& Wickens, M. (2012). Optimal monetary policy using an unrestricted VAR. Journal of Applied Econometrics, 27, 525-553.

Ricci, L. A. (1997). A Model of An Optimum Currency Area (IMF Working Paper, 97/76), Washington, DC: International Monetary Fund.

Rose, A. K. (2008). Is EMU Becoming an Optimum Currency Area? The Evidence on Trade and Business Cycle Synchronization. Berkeley: University of California.

Salvatore, D. (2002). Euro, the European Central Bank, and the International Monetary System. Annals of the American Academy of Political and Social Science - Exchange Rate Regimes and Capital Flows, 579, 153-167.

Schiliro, D. (2017). Imbalances and Policies in the Eurozone (MPRA Working Paper, 82847), Munich: Munich Personal RePEc Archive.

Serwa, D. \& Wdowiński, P. (2016). Macro-financial linkages in the Polish economy: combined impulseresponse functions in SVAR models (NBP, Working Papers 246), Warszawa: National Bank of Poland.

Sklias, P., \& Maris, G. (2012). Reassessment of the OCA criteria in the Euro area: the case of Greece. Int. J. Monetary Economics and Finance, 5(2), 124-138.

Torben W. H., Torben W., \& Kempa, B. (2008). Asymmetric Transmission of Monetary Policy in Europe: A Markov-switching Approach. Journal of Economic Integration, 23(4), 873-895. 
Verdun, A. (2007). Economic and monetary union. In: Cini, M. (ed), European Union Politics (pp. 324-339). Oxford: Oxford University Press.

Vrňáková, I., \& Bartušková, H. (2013). Is Euro Area an Optimal Currency Area and What Barriers Could Obstruct Its Future Development? ACTA VŠPS, 2(7), 123-144.

Wortmann, M., \& Stahl, M. (2016). One Size Fits Some: A Reassesment of EMU's Core-periphery Framework. Journal of Economic Integration, 31(2), 377-413.

Ulrich, M. (2018). Identification of financial and macroeconomic shocks in a VAR model of the Polish economy. A stability analysis. Economics and Business Review, 4(18), 29-43.

\section{MAKROEKONOMSKE DIVERGENCIJE I ASIMETRIČNE REAKCIJE UNUTAR EVRO ZONE}

$U$ radu se ispituje nominalna i realna divergencija unutar Evro-zone (EZ) kao osnova asimetrične monetarne transmisije Evropske centralne banke (ECB). Kako bi se rasvetlila pomenuta pitanja, deskriptivna analiza ključnih nominalnih i realnih indikatora potvrđuje dihotomiju jezgro-periferija unutar originalnih EZ12 članica, kao i specifičnu poziciju emergentnih članica EZ19. Monetarna transmisija (kanal kamatne stope) ispitana je pomoću ocenjenog Vektorskog autoregresionog (VAR) modela za zemlje predstavnike jezgra (Nemačka, Francuska, Belgija), kao i zemlje periferije (Portugal, Španija i Grčka) za period 1999Q1-2018Q4. Posmatrajući transmisiju kamatne stope ECB (šk) na promene rasta bruto domaćeg proizvoda (odgovor, reakcija), rezultati dekompozicije varijanse $i$ impulsnih odgovora ukazuju da generalno kanal kamatne stope deluje kontraciklično. Međutim, dok je stabilizirajući (kontracikličan) efekat evidentan za jezgro (posebno Nemačku), skoro da izostaje u slučaju Grčke. Zaključci naglašavaju osetljivost EZ u kontekstu heterogenog članstva $i$, posledično, asimetričnog odgovora na monetarne impulse ECB. Naši nalazi podržavaju argumente brojnih istraživačkih radova u kojima se naglašava dualizam jezgro-periferija, hipoteza nemačke dominacije, kao i "jedna odgovara nekima" monetarna politika.

Ključne reči: Evro-zona, jezgro, periferija, realna i nominalna divergencija, ECB, monetarna transmisija. 